Maria Zmierczak (Poznań)

\title{
Political and legal doctrines as a teaching subject at legal studies in the Third Polish Republic
}

\section{A LITTLE BIT OF PREHISTORY AND HISTORY}

Professor Małgorzata Materniak-Pawłowska, the editor of "Czasopismo Prawno-Historyczne" [The Journal of Legal and Historical Sciences] made the proposal of delineating the teaching subject entitled "Historia doktryn polityczno-prawnych" [The history of political and legal doctrines] or "Doktryny polityczno-prawne" [Political and legal doctrines] at the faculties of law. One has to admit that it is not an easy task as the author of the present article is able to describe this area of teaching only at the faculties of law of state universities. The subject "Political and legal doctrines" is taught not only in the course of legal studies but it is also often a part of the curricula of the administration or European law studies, which are frequently offered by the faculties of Law and Administration. Moreover, numerous monographic lectures are offered, such as "Historia polskiej myśli polityczno-prawnej" [The history of Polish political and legal thought]. However, the author will not enumerate the names of the subjects or the number of hours devoted to them at the respective faculties of law and at individual study majors as it was already delineated in a recently featured publication. ${ }^{1}$ Currently, there are many more schools and faculties of law in Poland. And that is the reason why the paper is devoted to literature and research as one can suspect that this subject is taught by the same people, and their former students, at private colleges.

${ }^{1}$ P. Kantor-Kozdrowicki, M. Materniak Pawłowska, J. Przygodzki, Legal and historical subjects at Polish faculties of law, "Czasopismo Prawno-Historyczne" [CPH, The Journal of Legal and Historical Sciences] 2019, Vol. LXXI, issue 2, pp. 291-301. 
Distinguishing this subject from the curriculum of legal studies has its importance in the aforementioned article. Even though such subjects as the history of the state and law were already a part of the planned curriculums of legal studies before the war, the only subject which was actually taught, and which partially included the same contents as the political and legal doctrine lecture, was the history of the philosophy of law. Nota bene, the terms philosophy of law and political doctrine were very clearly connected with each other. The evidence of this can be found in the form of a book published in Poznan in 1923. It is worth to recall its title page at this point: Paul Janet, Historia doktryn politycznych wraz z historia filozofii prawa. Przetożyła E. Rutkowska. Przejrzat i uzupetnit doktrynami politycznemi XIX i XX w. prof. dr A. Peretiatkowicz [Paul Janet, The History of political doctrines together with the history of the philosophy of law. Translated by E. Rutkowska. Reviewed and supplemented by the political doctrines of the $19^{\text {th }}$ and $20^{\text {th }}$ century by Professor A. Peretiatkowicz, Ph.D.]. This work was published in Poznań, Warsaw, and Toruń. It was composed of two volumes. The first volume of the book was entitled Od Sokratesa do Machiavellego [From Socrates to Machiavelli], while the second one was called Od Hobbesa do Duguita [From Hobbes to Duguit]. In the second volume, the part "Doktryny polityczne i prawno-filozoficzne XIX i XX wieku" [The political as well as legal and philosophical doctrines of the $19^{\text {th }}$ and $20^{\text {th }}$ century] by Professor A. Peretiatkowicz, Ph.D., starts from page 202. So much for the prehistory of the subject. It might also be worth mentioning that Antoni Peretiatkowicz, the rector of the University of Poznan between 1936 and 1939, concerned himself with the history of the philosophy of law and political thought already in his youth. As evidence of this, one can point to the fact that he obtained his habilitation, which was based on a paper on JeanJacques Rousseau, in 1914 in Cracow. Directly after the war, doctrinal elements, especially the knowledge of the classics and classical topics, such as natural law, social contract, the nature of the state, were taught as a part of the theory of the state and law as well the state law lectures, just like before the war. However, due to the imposed top-down methodology of Marxism-Leninism, according to which the only scientific approach was supposed to be the Marxist science of the state and law as an element of a superstructure on social class relationships. Even if Aristotle, Hobbes, or Locke were referred to, then as a rule an analysis of their claims was connected with criticism based on the fundamental theses of Marx. First and foremost, it was used to portray the class character of their doctrines as well as to show economic and political interests of a particular social class according to their representation. Nevertheless, scholars concerned themselves scientifically with ancient, early modern, and contemporary political thought. However, this did not arouse an enthusiastic reaction from the political authorities. In a confidential document of the Ministry of Higher Education from 1955, entitled "Ogólna ocena 
planów badań naukowych katedr uniwersyteckich w zakresie nauk prawnych na rok 1955" [The general evaluation of the planned scientific research of university departments concerning legal sciences in 1955], one can read:

Wspomnieć wreszcie należy o dyscyplinie, która formalnie nie jest reprezentowana $\mathrm{w}$ schemacie organizacyjnym uniwersytetów, ale zajmuje jednak nieostatnie miejsce w planach badań naukowych. Jest nią historia doktryn politycznych. Reprezentują ją katedry prawa państwowego i teorii państwa i prawa, a częściowo także historii państwa i prawa (zwłaszcza Kraków, Lublin i Poznań). Fakt ten sam w sobie nie budziłby zastrzeżeń, gdyż dyscyplina ta powinna być rozwijana przez naukę polską. Jednakże ujemną stroną zjawiska jest okoliczność, że tematyka $\mathrm{z}$ tej dziedziny absorbuje i tak już niedostateczne kadry pracowników dyscyplin tak ważnych i podstawowych, jak teoria państwa i prawa i prawo państwowe. [Finally, a discipline needs to be mentioned which is not formally represented in the organizational scheme of the universities; however, it does not occupy the last place in the scientific research plans. It is the history of political doctrines. It is represented by the departments of state law as well as of the theory of the state and law, and also partially by the history of the state and law (especially in Cracow, Lublin, and Poznań). This fact in and of itself would not raise objections as this discipline should be developed by Polish science. However, a negative side of this phenomenon is the circumstance that the subject matter of this area absorbs the workers from the staff of disciplines which are so important and fundamental, such as the theory of the state and law as well as state law, and they are already insufficient in numbers]. ${ }^{2}$

From the statement above, it seems reasonable to conclude that there were fewer people willing to teach the Marxist theory of the state and law than there were to teach and research other political ideas in Cracow, Lublin, and Poznań. However, the subject entitled "Historia doktryn polityczno-prawnych" [The history of political and legal doctrines], taught in the third year of legal studies, was reinstated in 1956. What is interesting is that this subject, taught by Konstanty Grzybowski in Cracow, by Grzegorz Leopold Seidler in Lublin, by Henryk Olszewski in Poznań, and also practised by Franciszek Ryszka in Warsaw as well as by Jan Baszkiewicz in Wrocław, ended in its scope, for the most part, at the beginning of the $20^{\text {th }}$ century. A scientific conference devoted to the creation of a system of the history of political and legal doctrines already took place in 1966 and it preceded work on coursebooks. ${ }^{3}$ The first one was published in 1967. Specifically,

2 Archiwum PAN [The Archive of the Polish Academy of Sciences], the Department in Poznań, P-III-27, resource 117, p. 43 (the whole text: pp. 42-49).

${ }^{3}$ A. Ajnenkiel, M. Senkowska, Konferencja naukowa $w$ Modlnicy poświęcona pracom nad systemem doktryn politycznych i prawnych [The scientific conference in Modlnica devoted to papers on the system of political and legal doctrines], CPH 1967, Vol. XIX, issue 1, pp. 221-225. 
it was the first edition of Konstanty Grzybowski's coursebook entitled Historia doktryn politycznych i prawnych [The history of political and legal doctrines]. The book contained a characteristic subtitle, namely Od państwa niewolniczego do rewolucyj burzuazyjnych [From the slave state to the bourgeois revolutions], while the last chapter (the $30^{\text {th }}$ one) was entitled "Polskie doktryny polityczne okresu Oświecenia" [Polish political doctrines from the Age of Enlightenment] ${ }^{4}$ In 1969, the first edition of the coursebook by Jan Baszkiewicz and Franciszek Ryszka, Historia doktryn politycznych i prawnych [The history of political and legal doctrines], appeared. It included a section on the doctrines of the $20^{\text {th }}$ century: The theories of social law and its sources; Functionalism and legal realism in America; The twilight of legal positivism. Normativism and decisionism; Authoritarianism and fascism as well as the Marxist-Leninist doctrine of the state and law in the fight with revisionism. The authors added ruminations concerning Soviet legal theorists, such as E. Paszukanis or P. Stuczka, in the third edition. However, they still considered that this lecture was historical in character and it should end at the point where the theory of the state and law, Marxist of course, should begin. It is worth mentioning the introduction from 1969 here:

Wykład dotyczy przeszłości. Piszemy o doktrynach, które można uważać za zamknięty rozdział historii, choć niektórzy twórcy bardzo niedawno odeszli z tego świata lub znajdują się wśród żyjących i zapewne liczyć mogą na naśladowców lub epigonów. Stosowne miejsce w wykładzie musiały znaleźć nauki twórców socjalizmu naukowego, które w społeczeństwie burżuazyjnym próbował zniekształcić rewizjonizm, a które odrodziły się i wzbogaciły w marksistowsko-leninowskiej doktrynie państwa i prawa. Doktryna ta i jej bezpośrednie antecedencje historyczne należą wszakże do innej dyscypliny naukowej: marksistowskiej teorii państwa i prawa. Książka kończy się w tym punkcie, gdzie naszym zdaniem zacząć się powinien wykład teorii państwa i prawa. [The lecture pertains to the past. We write about the doctrines which can be considered a closed chapter of history even though some authors have left this world very recently or they are among the living and they most probably can count on imitators and epigones. The teachings of the creators of scientific socialism, which revisionism in the bourgeois society tried to distort and which was reborn and enriched in the Marxist-Leninist doctrine of the state and law, had to find an appropriate place in the lecture. However, this doctrine and its direct historical antecedents belong to a different scientific discipline: the Marxist theory of the state and law. The book ends at the point where according to our opinion the lecture of the theory of the state and law should begin]. ${ }^{5}$

${ }^{4} \mathrm{~K}$. Grzybowski, Historia doktryn politycznych i prawnych. Od państwa niewolniczego do rewolucyj burżuazyjnych [The history of political and legal doctrines. From the slave state to the bourgeois revolutions], Warsaw 1967, the last chapter consists of pp. 422-434.

5 J. Baszkiewicz, F. Ryszka, Historia doktryn politycznych i prawnych [The history of political and legal doctrines], Warsaw 1973, preface to the $1^{\text {st }}$ edition, p. 5. 
The earlier publication (between 1956 and 1972) by Grzegorz Leopold Seidler was an important event. He published his Studia z historii doktryn [Studies of the history of doctrines], in three volumes, which was devoted to the political though of antiquity, the political thought of the Middle Ages, and to the political thought of the early modern period. In 1974, Grzegorz Leopold Seidler published an enormous volume entitled Przedmarksowska myśl polityczna [Pre-Marxist political thought] which ends with a description of liberalism and Hegel. ${ }^{6}$ In 1956, the Doktryny polityczno-prawne [Political and legal doctrines] subject appeared in the curriculums of legal studies. Departments and institutes dealing with research into this subject also appeared at the time. The first Department of the History of Political and Legal Doctrines in Poland was created in the 1961/1962 academic year. It was opened at the Jagiellonian University with Konstanty Grzybowski as its Head. ${ }^{7}$

Where did the name doctrine come from? The first and foremost reason was the necessity to differentiate the only scientific Marxist theory from the other theories and views concerning the state, society, and law. In this author's opinion, it is, in a way, explained by the notes of Antoni Peretiatkowicz, which possibly come from the beginning of 1956. On the three pages of the manuscript, with the heading Historia doktryn politycznych [The History of Political Doctrines], one can read the following:

Przystępując do wykładu historii doktryn politycznych musimy przede wszystkim zastanowić się, co wyraz "doktryna polityczna" oznacza? Wyraz ten jest pochodzenia łacińskiego i oznaczał zrazu wszelkie systematyczne rozumowanie, wszelką teorię, wszelką wiedzę. Mówiło się więc w Rzymie o doktrynie fizycznej czy matematycznej tak samo, jak o doktrynie prawnej. Jeszcze teraz, jeżeli ktokolwiek z państwa będzie składał doktorat na wydziale prawniczym, to złoży przy tym przysięgę w języku łacińskim, przysięgę, w której znajduje się następujące zdanie: "postquam examinibus legis laudabilem in universo iure doctrinam probavit." W językach współczesnych jednak wyraz "doktryna" zyskał znaczenie nieco odmienne. A mianowicie w pierwszej połowie XIX wieku na terenie francuskim po restauracji Burbonów powstała w parlamencie francuskim grupa polityczna, na czele której stał historyk Guizot, a która dążyła do przeszczepienia na teren francuski różnych instytucyj angielskich, nie bardzo dopasowanych do ówczesnych warunków we Francji. Ponieważ grupa ta nie liczyła się z ówczesną rzeczywistością historyczną we Francji, przeto nazywano ich doktrynerami, "les 1974.

${ }^{6}$ G.L. Seidler, Przedmarksowska myśl polityczna [Pre-Marxist political thought], Cracow

7 I. Barwicka-Tylek, Pamięć o Konstantym Grzybowskim [The memory of Konstanty Grzybowski] [in:] M. Maciejewski, M. Marszał, M. Sadowski (eds.), Tendencje rozwojowe myśli politycznej i prawnej [Developmental tendencies of the political and legal thought], Wrocław 2014, pp. 31-39. 
doctrinaires." Od tego czasu zaczęto używać wyrazu “doktryna” na oznaczenie teorii opartej raczej na rozumowaniu abstrakcyjnym aniżeli na doświadczeniu realnym. Przy tym obecnie używa się wyrazu "doktryna" dla oznaczenia takich teorii, które są związane z pewną dziedziną postępowania ludzkiego. Mówimy więc o doktrynie politycznej, doktrynie ekonomicznej, doktrynie etycznej, ale nie mówimy o doktrynie astronomicznej ani o doktrynie matematycznej, ani o doktrynie botanicznej. Zapytajmy się teraz, co znaczą wyrazy "doktryna polityczna"? Mówiąc ogólnie doktryna polityczna znaczy to samo co teoria państwowa z tym jednak zastrzeżeniem, że chodzi tu o przewagę rozumowania nad doświadczeniem i że chodzi tu nie tylko o to, czym państwo jest, ale także czym państwo być powinno. Doktryna polityczna jest to teoria, dotycząca istoty państwa, czyli zadań władzy państwowej. Historia doktryn politycznych ma znaczenie teoretyczne i znaczenie historyczne. Znaczenie teoretyczne na tym polega, że historia doktryn politycznych przedstawia różne sposoby rozwiązywania zagadnień państwa, różne próby czynione pod tym względem i w ten sposób ułatwia teoretykom współczesnym należyte ujęcie i należyte rozwiązanie tych zagadnień. Historia doktryn politycznych ma również znaczenie historyczne. Przedstawiając bowiem teorie polityczne w różnych okresach historycznych, przedstawia nam równocześnie te czynniki ideologiczne, które wpływały silnie na powstanie samych faktów historycznych, samych wydarzeń historycznych. Czy można zrozumieć rewolucję angielską z XVII wieku bez znajomości doktryny politycznej Locke'a? Czy można zrozumieć wielką rewolucję francuską bez znajomości doktryn politycznych Russa i Monteskiusza? I czy można zrozumieć rosyjską rewolucję październikową bez znajomości doktryny politycznej Lenina. Dlatego właśnie wykład historii doktryn politycznych ma raczej charakter ogólnokształcący, ponieważ łączy w sobie punkt widzenia historyczny, filozoficzny i polityczny, a także częściowo punkt widzenia socjologiczny. [When starting the lecture on the history of political doctrines, one must first think what the term "political doctrine" means? This word comes from Latin and it initially meant all systematic thinking, all theories, all knowledge. So physical or mathematical doctrines were talked about in the same way in Rome as about the legal doctrine. Even now, if anyone of you ladies and gentlemen receives a Ph.D. at a faculty of law, then you will simultaneously take an oath in Latin which contains the following sentence: "postquam examinibus legis laudabilem in universo iure doctrinam probavit." However, the word "doctrine" has acquired a slightly different meaning in contemporary languages. To be specific, in the first half of the $19^{\text {th }}$ century on the French territory after the restoration of the Bourbons, a French political group was created in the parliament with Guizot, a historian, at its head, and it strived to transplant various English institutions to the French ground which were not particularly well suited to the contemporary conditions in France. Because this group did not take into account the contemporary historical reality in France, they were called doctrinaires, "les doctrinaires," for this very reason. From that time on, the word "doctrine" has been used to denote the theory based rather on abstract thinking than on real experience. Moreover, the word "doctrine" is currently used to denote such theories which are connected with a certain field of human behaviour. So we talk 
about a political doctrine, an economical doctrine, an ethical doctrine, but we do not talk about an astronomical doctrine, or about a mathematical doctrine, or about a botanical doctrine. Let us now ask what do the words "political doctrine" mean? Generally speaking, a political doctrine means the same thing as the state theory with the proviso that it means here the advantage of reasoning over experience and that it does not only mean here what the state is but also what the state should be. The political doctrine is a theory pertaining to the essence of the state meaning the tasks of the state authorities. The history of political doctrines has a theoretical meaning and a historical meaning. The theoretical meaning relies on the fact that the history of political doctrines represents different methods of solving issues connected with the state, various attempts made in this regard and thus it facilitates proper conceptualization and proper solving of these issues by modern theoreticians. The history of political doctrines also has a historical meaning. By presenting political theories in different historical periods, it simultaneously presents to us these ideological factors which strongly influenced the creation of the historical facts themselves, of the historical events themselves. Can one understand the $17^{\text {th }}$ century English Revolution without the knowledge of Locke's political doctrine? Can one understand the Great French Revolution without the knowledge of the political doctrines of Rousseau and Montesquieu? And can one understand the Russian October Revolution without the knowledge of Lenin's political doctrine? That is why the political doctrines lecture rather has the character of general education because it combines in it the historical, philosophical, and political points of view as well as a partially sociological point of view]. ${ }^{8}$

The subject of "Historia doktryn politycznych i prawnych" [The history of political and legal doctrines] was taught at every faculty of law in Poland. Scientists who very frequently concerned themselves with doctrines worked for the departments of the history of the state and law, the theory of the state and law, and even for the Roman law departments. It is not possible to enumerate all the people who initiated research and influenced the shape of the taught subject. Nevertheless, let us remind that among them were Konstanty Grzybowski, Grzegorz Leopold Seidler, Franciszek Ryszka, Karol Jonca, Wiktor Kornatowski, Jan Kodrębski, Mieczysław Maneli, and Marek Sobolewski. Many of them had to reorient themselves to a new research area. For instance, let us mention that Wiktor Kornatowski researched bank law before the war, and later he concerned himself with the theory of the state and law, and finally - mainly due to his knowledge of Greek and Latin - he dealt with the political and legal thought of antiquity. Marek Sobolewski began his work in the Department of State Law of the Jagiellonian University and he mainly dealt with the study of the system of government of the

8 The manuscript is in possession of Archiwum PAN [The Archive of the Polish Academy of Sciences], the Department in Poznań, P-III-27, resource 32, pp. 82-85. The manuscript contains short forms, such as "doktr" [doctr], "pol” [pol], which were decoded. 
state. However, he was extremely well-versed in European doctrines. Moreover, he published a voluminous tome with Barbara Sobolewska entitled Myśl polityczna XIX $i X X$ w. Liberalizm [The political thought of the $19^{\text {th }}$ and $20^{\text {th }}$ century. Liberalism] (1978) which even today is a priceless source of knowledge concerning the changes in liberalism. ${ }^{9}$ Jan Baszkiewicz was the Head of the Department of the History of Political and Legal Doctrines at the University of Wrocław since 1959, later of the Department of the General History of the State and Law at the University of Silesia, and later he ran the Institute of the History of Political Doctrines at the Department of Journalism at the University of Warsaw. Henryk Olszewski started out as a Polish state and law historian, similarly to Karol Jonca. Later, both of them became experts especially in the field of German political and legal thought. ${ }^{10}$

However, it is worth emphasizing that the coursebooks were undoubtedly subjected to strict control in regards to their conformity with the fundamental Marxist-Leninist thesis. On the other hand, numerous authors managed to avoid this subject matter in detailed research or in the publication of sources. The knowledge and familiarity with particular political doctrines grew significantly between 1970 and 1989. As an example, it is enough to mention voluminous publications devoted to liberalism, conservatism, or Catholic thought. The knowledge of Nazism, Italian fascism, French and Italian thought, and etc. was expanding.

Simultaneously, the familiarity with particular doctrines and their authors was developing and, even more importantly, Polish literature devoted not exclusively to the classics was growing. Indeed, the more distant subject matter was dealt with more eagerly as it was easier to write about Machiavelli, Modrzewski, or

${ }^{9}$ B. Sobolewska, M. Sobolewski, Myśl polityczna XIX i XX w. Liberalizm [The political thought of the $19^{\text {th }}$ and $20^{\text {th }}$ century. Liberalism], Warsaw 1978.

${ }^{10}$ Numerous recollections devoted to the deceased professors who had been the first ones to teach political and legal doctrines were included in: M. Maciejewski, M. Marszał, M. Sadowski (eds.), Tendencje rozwojowe... [Developmental tendencies...]. These texts are: M. Sadowski, Jan Baszkiewicz - historyk doktryn politycznych i prawnych [Jan Baszkiewicz - a historian of political and legal doctrines] (pp. 19-29); I. Barwicka-Tylek, Pamięć o Konstantym Grzybowskim [The memory of Konstanty Grzybowski] (pp. 31-39); M. Maciejewski, Wkład profesora Karola Joncy w rozwój nauk historyczno-prawnych [The contribution of Professor Karol Jonca to the development of historical and legal sciences] (pp. 41-50); Z. Rau, Wspomnienie o Janie Kodrębskim [In memory of Jan Kodrębski] (pp. 51-57); J. Justyński, Wiktor Kornatowski (1911-1975) historyk doktryn polityczno-prawnych, docent UMK [Wiktor Kornatowski (1911-1975), a historian of political and legal doctrines, an associate professor at the Nicolaus Copernicus University] (pp. 59-66); L. Dubel, Jan Malarczyk (pp. 67-72); H. Izdebski, Mieczysław Maneli (1922-1994); M. Maciejewski, Wkład profesora Franciszka Ryszki w rozwój nauk historyczno-prawnych politologii [The contribution of Professor Franciszek Ryszka to the development of historical and legal sciences of politology] (pp. 79-96); L. Dubel, Grzegorz Leopold Seidler (pp. 97-101); M. Jaskólski, Marek Sobolewski. Droga uczonego [Marek Sobolewski. The path of the scholar] (pp. 103-111). 
about the medieval doctrine of the church; however, the more modern ideas were already recognized. A question should be posed in this context whether the year 1980, the creation of NSZZ "Solidarność" [Independent Self-governing Trade Union "Solidarity"], and the numerous underground publications which came later, did not change the shape of the lectures and tutorials? It is because of "Nowa" [New] the first edition of Hannah Arendt's Korzenie totalitaryzmu [The Origins of Totalitarianism $]^{11}$ appeared as well as Kołakowski's Główne nurty marksizmu [Main Currents of Marxism] $]^{12}$, or Karl Raimund Popper's Spoteczeństwo otwarte i jego wrogowie [The Open Society and Its Enemies]. ${ }^{13}$

Just after the political transformation at the beginning of the $90 \mathrm{~s}$ of the $20^{\text {th }}$ century, numerous new coursebooks appeared. Among the books' authors were the Heads of the Departments of political and legal doctrines. The first new coursebook, chronologically speaking, was a book by Henryk Olszewski and Maria Zmierczak entitled Historia doktryn politycznych i prawnych [The history of political and legal doctrines] (1993). After this book came the following: Andrzej Sylwestrzak published Historia doktryn politycznych i prawnych [The history of political and legal doctrines] in 1994, a coursebook by Hubert Izdebski Historia myśli politycznej i prawnej [The history of political and legal thought] came out in 1995, ${ }^{14}$ Janusz Justyński's Historia doktryn polityczno-prawnych [The history of political and legal doctrines] was published in 1999, Stanisław Filipowicz's coursebook Historia myśli polityczno-prawnej [The history of political and legal thought] came out in 2001, Lech Dubel published his coursebook Historia doktryn politycznych i prawnych do końca XIX wieku [The history of political and legal doctrines until the end of the $19^{\text {th }}$ century] in 2002, Historia doktryn politycznych i prawnych. Podręcznik akademicki [The history of political and legal doctrines. A university coursebook], which was penned by Henryk Olszewski and Krystyna Chojnicka, was published in 2004, and a coursebook by Lech Dubel Historia doktryn politycznych i prawnych do schytku XX wieku [The history of

${ }^{11}$ H. Arendt, Korzenie totalitaryzmu [The Origins of Totalitarianism], Warsaw 1989, two volumes were published as a part of the "Biblioteka Kwartalnika Politycznego 'Krytyka"' [The Library of the "Critique" Political Quarterly] series.

${ }^{12}$ L. Kołakowski, Główne nurty marksizmu. Powstanie - rozwój - rozkład [Main Currents of Marxism. Its Origins, Growth and Dissolution], $1^{\text {st }}$ domestic edition, 1981. It was a reprint of the 1976 edition by the Literary Institute in Paris.

${ }^{13}$ In 1987, Niezależna Oficyna Wydawnicza published K.R. Popper's Spoleczeństwo otwarte $i$ jego wrogowie [The Open Society and Its Enemies] as a part of the "Biblioteka Kwartalnika Politycznego "Krytyka'". It was written about by Adam Chmielewski in the editorial note, see: K.R. Popper, Spoleczeństwo otwarte i jego wrogowie [The Open Society and Its Enemies], Vol. 1: Urok Platona [The Spell of Plato], Warsaw 1993, p. 9.

${ }^{14} \mathrm{H}$. Izdebski, Historia myśli politycznej i prawnej [The history of political and legal thought], Warsaw 1995. 
political and legal doctrines until the end of the $20^{\text {th }}$ century] was released in 2005. Other titles should also be enumerated: Doktryny polityczne XIX i XX wieku [The political doctrines of the $19^{\text {th }}$ and $20^{\text {th }}$ century] edited by Krystyna Chojnicka and Wiesław Kozub-Ciembroniewicz, Marcin Król's Historia myśli politycznej od Machiavellego po czasy wspótczesne [The history of the political thought from Machiavelli to contemporary times] (2005), Iwona Barwicka-Tylek and Jacek Malczewski's Historia myśli ustrojowej i społecznej [The history of the system of government and social thought] from 2009, Idee i doktryny polityczne XX wie$k u$. Wybór [Political ideas and doctrines of the $20^{\text {th }}$ century. A selection], edited by Andrzej Wojtaszak and Dariusz Wybranowski (2003), a university textbook Wspótczesne doktryny polityczne i prawne. Twórcy - idee - interpretacje [Modern political and legal doctrines. Its creators, ideas, and interpretations], edited by Wiesław Kozub-Ciembroniewicz, Bogdan Szlachta, Anna Citkowska-Kimla and Małgorzata Kiwior Filo (2012).

These coursebooks were intended for law, politology, and administration students. At the same time, source texts were published and first among them was Wybór tekstów źródlowych z historii doktryn polityczno-prawnych [A selection of source texts from the history of political and legal doctrines] by Janusz Justyński from 1994. ${ }^{15}$ In 1996, a selection of texts entitled Naród. Państwo. Władza [The nation. The state. The power] was printed which was devoted to Polish political thought and it was edited by the following team: Barbara Bankowicz, Włodzimierz Bernacki, Antoni Dudek, Michał Jaskólski, Jacek Majchrowski, Bogdan Szlachta, and Jan Wiszniewski. ${ }^{16}$ Włodzimierz Bernacki, Krystyna Chojnicka, Michał Jaskólski, and Bogdan Szlachta published their collection Historia doktryn politycznych i prawnych. Wybór źródet [The history of political and legal doctrines. A selection of sources]. ${ }^{17}$ A voluminous, two-tome selection of sources entitled Historia idei politycznych [The history of political ideas] was published by Stanisław Filipowicz, Adam Mielczarek, Krzysztof Pieliński, and Maciej Tański. ${ }^{18}$ In 2003, an extremely extensive selection of texts appeared which

15 Wybór tekstów źródlowych z historii doktryn polityczno-prawnych [A selection of source texts from the history of political and legal doctrines], selection made and edited by J. Justyński, Torun 1994. The $2^{\text {nd }}$ edition from 2004 was extended with additional texts by Alexis de Tocqueville, Kautsky and Lenin.

${ }^{16}$ Naród. Państwo. Władza. Wybór tekstów z historii polskiej myśli politycznej dla studiujących prawo, nauki polityczne i historie [The nation. The state. The power. A selection of texts from the history of the Polish political thought for the students of law, political sciences, and history], Cracow 1996.

17 W. Bernacki, K. Chojnicka, M. Jaskólski, B. Szlachta, Historia doktryn politycznych i prawnych. Wybór źródet [The history of political and legal doctrines. A selection of sources], Sopot 1997.

${ }_{18}$ S. Filipowicz, A. Mielczarek, K. Pieliński, M. Tański, Historia idei politycznych. Wybór tekstów [The history of political ideas. A selection of texts], Warsaw 2002 and 2001. The second volume appeared one year before volume 1 . 
constituted a supplement to the Lublin coursebook by Lech Dubel. ${ }^{19}$ Moreover, dictionaries were published which presented political and legal ideas as well as their eminent creators. First and foremost among them were Leksykon myślicieli politycznych i prawnych [The lexicon of political and legal thinkers], edited by Elżbieta Kundera and Marek Maciejewski, as well as the great Stownik historii doktryn politycznych [A dictionary of the history of political doctrines], edited by Michał Jaskólski, which was composed of six volumes and published by Wydawnictwo Sejmowe between 1997 and 2015. Over 40 researchers took part in this enterprise. ${ }^{20}$ To sum up this part of the ruminations, it should be emphasized that the paucity in the familiarity with the political thought was very quickly remedied (beginning already in the 80s), research areas were extended, and the knowledge of literature was enlarged, especially of the latest literature. In short, researchers were freeing themselves from the Marxist-Leninist methodology and they expanded their field of interest. The backlog of work was being caught up with. It should suffice to say that Locke was only translated into Polish in 1992. As a side note, it should be mentioned that the bibliography edited and translated in "Czasopismo Prawno-Historyczne" contains those publications under the heading of position 6 which was separated as Historia doktryn prawnych i programów spoleczno-ustrojowych [The history of legal doctrines as well as of social and system of government programmes]. The following question should be asked - do the political doctrines not count? Or maybe the Journal only concerns itself with views pertaining to law and maybe not to the state?

A significant element which also influenced the development of research was the reactivation of the politological studies in the $60 \mathrm{~s}$. The reactivation or creation of the new major as well as of new institutes of political sciences resulted sometimes in a division of the departments. It happened, for instance, in Cracow, Lublin, and Warsaw. It had one important result, namely the difficulty in answering the following questions: what lawyers should be taught; what differentiates the political doctrine from the legal doctrine; and where bigger emphasis should be put? It happened that the doctrines were taught and researched within one department like in Katowice, for example. Ryszard Małajny, who was the Head of this Department, taught constitutional law as well as political and legal doctrines

${ }^{19}$ L. Dubel, J. Kostrubiec, G. Ławnikowicz, M. Łuszczyńska, W. Więcław, Historia doktryn politycznych i prawnych do początku XX wieku. Materiaty źródlowe, wybór i opracowanie [The history of political and legal doctrines until the beginning of the $20^{\text {th }}$ century. Source materials, selected and edited], Lublin 2003.

${ }^{20}$ See the review by M. Zmierczak, Stownik historii doktryn politycznych [A dictionary of the history of political doctrines], Vol. 1: $A-C$; Vol. 2: $D-H$; Vol. 3: $I-Z$; Vol. 4: $M-Q$; Vol. 5: $R-S$; Vol. 6 : $T-Z$ with a supplement, scientific editor: M. Jaskólski, Warsaw 1997-2015, pp. 4154 [in:] "Państwo i Prawo" [The State and Law], 2017, R. LXXII, issue 10 (860), pp. 124-127. 
there. Moreover, after 1989, the majority of the departments at the faculties of law stopped being the departments of "teoria państwa i prawa" [the theory of the state and law] and they most frequently became the departments of "teoria i filozofia prawa" [the theory and philosophy of law], while the departments of constitutional law were often combined with the doctrines. Then, the problem of the contents of teaching appeared which was further exacerbated by the issue of the scope, methods, and the specificity of teaching the subject to law students. It is also worth noticing that some researchers continued their interests in the theory of the state and law by frequently writing about the philosophy of law. For example, Maria Szyszkowska who in numerous publications about Kant, for instance, employs the term "filozofia prawa" [the philosophy of law] or Roman Tokarczyk who authored of Historii filozofii prawa $w$ retrospektywie prawa natury [The history of the philosophy of law in the retrospective of natural law]. ${ }^{21}$

\section{THE INTEGRATION OF THE COMMUNITY \\ OF RESEARCHERS, LAWYERS, AND POLITOLOGISTS WHO RESEARCHED POLITICAL AND LEGAL DOCTRINES}

The community of the younger generation of researchers, who taught the subject not only at the faculties of law, had a highly developed need of not only integrating itself but also of expanding its own knowledge as well as of broadening the methodological reflection. The clearest proof of this was initiating a conference which gathered the academic teachers of the subject of "Historia doktryn politycznych i prawnych" [The history of political and legal doctrines]. On the initiative of the Wrocław community, mainly of Professor Marek Maciejewski, conferences have started to take place since 2001 which gather doctrine researchers, separately from the conferences of the state and law historians. The results of the conferences are publications which very frequently raised methodological problems. The first conference took place in Świeradów in $2001 ; 22$ another conference, which was organized by Professor Lech Dubel and his associates from the Maria Curie-Skłodowska University, took place in Krasnobród in $2002 ;^{23}$ a conference entitled "Własność w myśli politycznej i prawnej" [Property in the polit-

${ }^{21}$ R. Tokarczyk, Historia prawa w retrospektywie prawa natury [The history of the philosophy of law in the retrospective of natural law], Białystok 1999; M. Szyszkowska, Europejska filozofia prawa [The European philosophy of law], Warsaw 1993.

22 The fruit of their labour was a publication: M. Maciejewski, M. Marszał (eds.), Doktryny polityczne i prawne u progu XXI wieku [Political and legal doctrines at threshold of the $21^{\text {st }}$ century], Wrocław 2002.

${ }^{23}$ See the publication: L. Dubel (ed.), Idee jako źródło instytucji politycznych i prawnych [Ideas as a source of political and legal doctrines], Lublin 2003. 
ical and legal thought] was organized by Professor Zbigniew Rau in Sulejów in 2003. ${ }^{24}$ In 2005, a conference devoted to the subject matter of natural law, which was organized by the Department of the History of Political and Legal Doctrines of the Adam Mickiewicz University, took place in Gniezno. ${ }^{25}$ Another conference, the fifth one, took place in Szczyrk in 2006. It was organized by Professor Ryszard Małajny and the Department of Constitutional Law as well as of Political and Legal Doctrines of the University of Silesia. ${ }^{26}$ The next one took place in 2007 in Cracow and the conference was entitled "Czas, idee, interpretacje" [Time, ideas, interpretations]. ${ }^{27}$ In 2008, the $7^{\text {th }}$ Polish Nationwide Conference of the Departments and Institutes of the History of Political and Legal Doctrines on "Kultura i myśl polityczno-prawna" [Political as well as legal culture and thought] took place in Jurata; ${ }^{28}$ the $8^{\text {th }}$ congress of the departments took place in Torun in 2009; ${ }^{29}$ in 2011, attendees debated on "Polska i Polacy w oczach cudzoziemców. Polacy wobec cudzoziemców" [Poland and Poles in the eyes of foreigners. Poles towards foreigners] in Kazimierz Dolny; the $10^{\text {th }}$ Congress of the Departments of Political and Legal Doctrines was organized by the Wrocław Department in Szklarska Poręba in 2012; ${ }^{30}$ the $11^{\text {th }}$ congress about "Wolność w myśli społecznej, politycznej i prawnej" [Liberty in social, political, and legal thought] was in Uniejów in 2013 and, in its aftermath (albeit a distant one), a huge work consisting of three volumes has been recently published. The work is entitled "Wolność człowieka i jej granice" [The liberty of man and its boundaries] and its editor is Olgierd Górecki. By writing "odległe pokłosie" [a distant aftermath], the author of this paper means that the topic of the conference and the papers presented there became a source of inspiration to invite other authors and so readers receive a wide scope of understanding of the term "wolność" [liberty] by various authors

${ }^{24}$ The material from this conference was published in CPH 2004, Vol. LVI, issues 1 and 2.

${ }_{25}$ M. Zmierczak (ed.), Prawo natury w doktrynach polityczno-prawnych Europy [Natural law in the political and legal doctrines of Europe], Poznań 2006.

${ }_{26}$ R.A. Małajny (ed.), Konstytucjonalizm a doktryny polityczno-prawne. Najnowsze kierunki badań [Constitutionalism and political and legal doctrines. The latest research directions], Katowice 2008.

${ }^{27}$ K. Chojnicka, A. Citkowska-Kimla, W. Kozub-Ciembroniewicz (eds.), Czas a trwanie idei politycznych i prawnych [Time and the endurance of political and legal ideas], Warsaw 2008.

28 A. Sylwestrzak, D. Szpoper, A. Machnikowska, P. Dąbrowski (eds.), Kultura i myśl polityczno-prawna. Materiały z VII Ogólnopolskiego Zjazdu Katedr Doktryn Politycznych i Prawnych, Jurata, 28-31 maja $2008 \mathrm{r}$. [Political as well as legal culture and thought. Materials from the $7^{\text {th }}$ Polish Nationwide Conference of the Departments and Institutes of the History of Political and Legal Doctrines, Jurata, 28-31 May 2008], Sopot 2010.

${ }^{29}$ J. Justyński, A. Madeja (eds.), Moralność i władza jako kategorie myśli politycznej [Morality and power as categories of political thought], Warsaw 2011.

${ }^{30}$ M. Maciejewski, M. Marszał, M. Sadowski (eds.), Tendencje rozwojowe... [Developmental tendencies...]. 
through different times and of diverging contents. ${ }^{31}$ In 2014 , the $12^{\text {th }}$ congress of the departments in Cracow brought about a debate on "Myślenie o polityce i prawie" [Thinking about politics and law]; $;^{32}$ the $14^{\text {th }}$ congress of the departments of the History of Political and Legal Doctrines entitled "Historia myśli politycznej i prawnej a prawo i kultura prawna" [The history of political and legal thought in relation to law and legal culture] took place in Białystok in 2015. The $16^{\text {th }}$ congress of the Departments of Political and Legal Doctrines in Warsaw in 2017 was devoted to ruminations concerning the terms of evolution and revolution. ${ }^{33}$ The $17^{\text {th }}$ Polish Nationwide Congress of the Departments of Political and Legal Doctrines, which took place in Wrocław in 2018, was devoted to the Polish political and legal thought. ${ }^{34}$ Some congresses were connected with Polish nationwide congresses of historians of law and system of government. In 2016, a congress in Mragowo (the $15^{\text {th }}$ one) was entitled "Pogranicza w historii prawa i myśli polityczno-społecznej" [The borderlands of the history of law and of the political and social thought] ${ }^{35}$ while the congress in Lublin in 2019 (the $18^{\text {th }}$ one) was called "Wojny $i$ ich wplyw na przemiany ustroju, prawa, myśli politycznej" [Wars and their influence on the changes of the system of government, law, and political thought]. ${ }^{36}$

Even an overview of the raised topics indicates that the interests of the historians of doctrines are extremely diverse and wide. However, when they were released from the Marxist methodological constraints, the issue of the didactics of the subject turned out to be of extraordinary significance. It went hand in hand with the acquisition of new contents, meeting contemporary authors, new ideas, such as libertarianism or American communitarianism, open possibilities of the analysis of totalitarian terms and doctrines, also of the communist totalitarianism,

${ }^{31}$ O. Górecki (ed.), Wolność człowieka i jej granice. Antologia pojęcia w doktrynach polityczno-prawnych [The liberty of man and its boundaries. An anthology of the term in the political and legal doctrines], Vol. I: Od starożytności do Monteskiusza [From the antiquity to Montesquieu], pp. 448; Vol. II: Od Cato's Letters do klasyków anarchizmu [From Cato's Letters to the classics of anarchism], pp. 564; Vol. III: Od Nietzschego do wspótczesności [From Nietzsche to modernity], pp. 545, Łódź 2019.

${ }^{32}$ I. Barwicka-Tylek, A. Czarnecka, M. Jaskólski, J. Malczewski (eds.), Myślenie o polityce i prawie. Przedmiot. Metoda. Praktyka [Thinking about politics and law. The subject. The method. The practice], Warsaw 2015.

33 A. Bosiacki (ed.), Rewolucjonizm i ewolucjonizm w doktrynach polityczno-prawnych [Revolutionism and evolutionism in the political and legal doctrines], Warsaw 2020.

${ }^{34}$ M. Maciejewski, M. Marszał, M. Sadowski (eds.), Od niepodległości do niepodległości. Polska myśl polityczna i prawa 1918-2018 [From independence to independence. The Polish political and legal thought between 1918 and 2018], Wrocław 2019.

${ }_{35}$ D. Szpoper, P. Dąbrowski (eds.), Pogranicza w historii prawa i myśli polityczno-prawnej [The borderlands of the history of law and of political and legal thought], Gdańsk - Olsztyn 2017.

${ }^{36}$ See the publication of the papers in: "Annales Universitatis Mariae Curie-Skłodowska", Sectio G - Ius, 2019, Vol. XVI. 
and finally with the liberty to create the curriculum of the studies. All of this did not make it easier to work out the finer details of a common approach to the subject of "doctrine" at legal studies. On the other hand, due to a lack of possibility of central control, authors could mark their broadened interests, mark their knowledge. The issues remain open even now. Admittedly, the aforementioned coursebooks retain the chronology of the appearance of ideas. Naturally, they contain a division into time periods - antiquity, middle ages, early modern period, the $17^{\text {th }}$ century, Enlightenment, the $19^{\text {th }}$ and $20^{\text {th }}$ century in which the interwar period is separate. Needless to say, each and every coursebook makes mention of Athenian democracy, Plato, Aristotle, Saint Augustine, Thomas Aquinas, and they always mention Machiavelli and Bodin, there is Hobbes, Locke, Montesquieu, there is Burke, Constant, Tocqueville, Mill, etc. In short - all the classics are present. The analysis should start with a question, namely what knowledge should the subject called "Doktyny polityczno-prawne" [Political and legal doctrines] give? Should it be a history lecture explaining how the state and law were understood from the most ancient times to the present day? Should it concern itself with great thinkers from the past or should it analyze the latest trends? Should it, and to what extent, deal with and present an analysis of the doctrines against the backdrop of a broadly outlined historical background, while at the same time taking into consideration the life of a given thinker? Or should it rather analyze that what has turned out to be fertile, enduring, and alive? Should it take into consideration the philosophical fundamentals of a given political viewpoint or should it rather concentrate on their vision of the state itself? Naturally, it is not possible to discuss Locke's entire philosophy, his epistemology, etc., while considering his political views; on the other hand, without familiarity with Aristotle's scientific method, it is not possible to understand his political views. It is this author's opinion that the history of philosophy is only a background, but it is necessary to present the philosophical background while analyzing the political and legal ideas of some important thinkers. It is not especially interesting to us whether Benjamin Constant was an idealist, a materialist, but we are only concerned with how he differentiated between ancient and contemporary liberties. However, in Plato's case, his philosophy, its ontological assumption of the existence of ideal beings which can only be grasped by the mind, is extremely significant in order to understand Plato's formula of the ideal state. Why do we learn it then? Well, because making certain assumptions has its consequences. Also legal consequences: in Plato's case, law understood as a general rule is not necessary in the ideal state as wise men know justice and they will judge every case in accordance with the idea of justice. However, in the $20^{\text {th }}$ century, Lon Luvois Fuller convinced us in his work entitled Moralność prawa [The morality of law] that legal norms should be formulated as general and abstract. Finally, should one, and to what extent, concern oneself with theories of 
law since they are frequently taken into account by law theorists, such as Formula Radbrucha [The Radbruch formula] by Jerzy Zajadło, for instance. Should one adhere to chronology? Or should one create a coursebook, especially in the part concerning the $19^{\text {th }}$ and $20^{\text {th }}$ century, in such a way as to present the evolution of, e.g., liberalism, conservatism, socialism or the social doctrine of the Catholic Church? It is worth pointing out that it was considered how the term of natural law and the term of liberty have been changing and how differently they are explained in various doctrines. Finally, the issue of sources presented itself: should one draw on philosophy, or on the theory of law, or on the theory of the state? However, the most important problem was the issue of the scope of the subject matter that the lecture should encompass: should one deal with the European thought or with the Euro-Atlantic one and present its development, which was also based on Christianity after all, and later on the social and political teachings of Luther, Calvin, or of the Catholic church; or should it also take into consideration the culture of the East or be based on Islam? Mirosław Sadowski, who is particularly active in that last matter, emphasizes that familiarizing oneself with the political doctrine of Islam is especially important in the globalization period as it is connected with the confrontation of the Christian culture with the Islamic culture, similarly to the political culture of the East, as a confrontation with China and with the East awaits us, but definitely not with the political culture as it has been individualistic from the earliest of times. ${ }^{37}$ Finally, a question pertaining to the sources arises: should one research only the great thinkers and their works, or should one also take into consideration political party programmes, collections of papers, etc. Another question: should one concern oneself with the concepts of the state which are still applied, namely the human rights concept, the separation of powers concept, the concept of liberty, or should it simply present the historical development? What should be researched: the thought or its social interaction which could have been conducive and was conducive to change?

It commenced with the change of the term "doktryna" [doctrine]. First and foremost, the term "historia" [history] was removed from the name of the subject. The latter stemmed from the curriculum which included political and legal doctrines as well as views of legal academics. It happened in 2007 but, as the freedom to create curriculums was reinstated, the word "history" did not disappear from the name of the subject everywhere. It is this author's personal opinion that the term "doktryna" [doctrine] has its justification as I find Professor Peretiatkowicz's

${ }^{37}$ M. Sadowski, Pomiędzy Kiplingiem i Saidem. Myśl polityczno-prawna w dobie globalizacji [Between Kipling and Said. The political and legal thought in the period of globalization] [in:] I. Barwicka-Tylek, A. Czarnecka, M. Jaskólski, J. Malczewski (eds.), Myślenie o polityce i prawie... [Thinking about politics and law...], pp. 109-121. 
explanation extremely convincing. Moreover, it has one advantage: a doctrine does not have to be expressed in a grand philosophical system and yet it contains clear notions pertaining to how a state and society are to be organized, and what law should be. "Idea" [Idea] is too broad a term for jurisprudence. The problem lies in the fact that the term "doctrine" has such an unambiguous connotation with indoctrination that, first, the term history was disposed of quickly and, later, doctrine was substituted with "myśl" [thought] or with "idea" [idea]. Secondly: do we deal with any views, or with such views which have endured or maybe which have guided thinking as well as real systems of government, such as liberal democracy, totalitarianism, or authoritarianism. An issue of substantial proportions is also the question regarding the place of Polish authors and of the Polish political thought as it is very frequently identified with the current politics of memory, especially when it is colloquially said that everybody else can learn democracy from us, and noble's democracy is frequently presented as an argument. On the one hand, it is obvious that it is worthwhile to recall the forgotten Polish thinkers. On the other hand, they should not be presented without portraying a historical background and without a confrontation with other parallel cultures. If one remembers that law was in reality above the king in Poland, then it is also worth mentioning the practice of applying law which was not really that good. The last part is frequently connected with the remembrance of the classics of the Polish political thought. Just to give an example, one can recall a series in which all the works by Aleksander Fredro and other Polish authors were published. However, a problem pertaining to selection arises here. Should the lecture include the Polish tradition of political thinking and to what extent if the answer is in the affirmative.

The currently binding coursebooks reflect the interests of their authors. The contents of the lecture most frequently encompass the European or Euro-Atlantic political thought. Admittedly, chapters pertaining to the legal thought from outside of Europe are added once in a while. For instance, one can encounter this in Janusz Justyński's coursebook in the chapter entitled "U źródeł cywilizacji i refleksji politycznej" [At the source of civilization and political reflection]. The book's chapters 1 to 5 contain a description of "Refleksja polityczna w myśli starożytnego Egiptu" [The political reflection in the thought of Ancient Egypt], "Refleksja polityczna ludów Mezopotamii" [The political reflection of the peoples of Mesopotamia], "Refleksja polityczna Chin starożytnych" [The political reflection of ancient China], "Myśl polityczna Indii starożytnych" [The political thought of ancient India] as well as "Główne wątki refleksji politycznej dawnego Izraela" [The main points of the political reflections in Israel of old].$^{38}$ More-

38 J. Justyński, Historia doktryn polityczno-prawnych [The history of political and legal doctrines], Toruń 2000 ( $1^{\text {st }}$ edition: 1997), pp. 27-48. 
over, Lech Dubel devoted two chapters to remind readers the political and legal doctrines of ancient China and "Poglądy polityczno-prawne Wschodu" [The political and legal views of the East] (Mesopotamia, Buddhism, Judaism). ${ }^{39}$ The remaining coursebooks are rather justified in their focus on the European thought as it grew out of the tradition of Ancient Greece, Rome, and Christianity. More attention is also devoted to the Christian thought, to the contemporary one as well, which is in accordance with democracy and with free conscience, which is significant after all.

On the one hand, there are researchers who concern themselves with the study of the political and legal thought of particular authors. Numerous monographs have been created, such as the ones about Benjamin Constant, John Stuart Mill, Ferguson, Trocky, and Lenin; the thoughts of Hume and Spencer have been analyzed. On the other hand, essays have been created which present Russian constitutionalism; the political and legal thought of Poland, Germany, France, Russia, and the USA; conservatives and libertarians; the justice of law; contemporary versions of the welfare state, or of servicing administration. The author of the article would like to apologize at this point to all the authors who were not mentioned. However, it would probably be necessary to create a complete bibliography of the subject in order to do that, which is not possible due to space constraints. Nevertheless, it is certain that all of this knowledge pertaining to the thinking about the state and law cannot be present in a university textbook.

\section{THE METHODOLOGICAL AWARENESS OF RESEARCHERS AND THE STATE ACTIVITY \\ WHICH INFLUENCE THE POSITION OF THE SUBJECT IN THE CURRICULUM OF LEGAL STUDIES}

Those conducting research into the political and legal thought at the faculties of law at Polish universities have an extremely developed methodological awareness. Firstly, they have the awareness that they are most concerned with various justifications of the creation of the state and the scope of the state authority as well as with the issue of the power of the existing law. However, they do not necessarily concern themselves with the issue of theological differences between Saint Ambrose and Saint Augustine if they bear no significance in relation to the justification of the rationale behind the existence of the state according to these thinkers. Also, contrary to politologists, they are not necessarily interested

${ }^{39}$ L. Dubel, Historia doktryn politycznych i prawnych do schyłku XX wieku [The history of the political and legal doctrines until the end of the $20^{\text {th }}$ century], Warsaw 2009 ( $1^{\text {st }}$ edition: 2005), pp. 29-44. 
in the current programmes of political parties but they are rather interested in from which doctrines and from which thinkers those who influenced the shape of the state and its system of government drew on. They are interested in those ideas which influenced the shape of particular systems of government or organized political life according to certain principles, for example, such as social Darwinism or Marxist-Leninism, rather than in the specific shape of the Cuban system of government and the views of Fidel Castro, for instance. Methodological problems have a very important position in the materials from the Wrockaw and Cracow conferences. Above all, it is worth mentioning an article by Marcin Niemczyk entitled Historia doktryn polityczno-prawnych w świetle europejskich i krajowych ram kwalifikacji [The history of the political and legal doctrines in light of the European and domestic framework of qualification]. In the paper, the author indicated that the history of doctrines became an optional subject starting from 2001. Moreover, the significance of the subject was to be connected with the so-called learning outcomes which were connected with practical skills. ${ }^{40}$

A lot of attention was devoted to these methodological problems during the aforementioned conference organized in Cracow in 2014. In its aftermath, an elegant volume entitled Myślenie o polityce i prawie [Thinking about politics and law] was published. Numerous articles which are included in it pertain to methodology and they concern the scope of research, the shape of the lecture, and the shape of the classes in the form of tutorials. Incidentally, it is worth adding that Professor Michał Jaskólski, who was the Head of the Department of the History of Political and Legal Doctrines at the Jagiellonian University until recently, has always been deeply interested in this subject matter. His ruminations in $O$ interdyscyplinarności historii doktryn [On the interdisciplinarity of the history of doctrines] are a proof of this. ${ }^{41}$

One of them is a very voluminous text by Marek Maciejewski and Tomasz Scheffler entitled $O$ doktrynologii: rozważania dotyczace przedmiotu oraz metody doktryn politycznych i prawnych [Doctrinology: ruminations concerning the subject as well as the method of political and legal doctrines]. A significant element of this text is an attempt to define the area of research of "doktrynerzy" [doctrinaires] and later a critical attempt to portray the historical approach, which was termed as "meliorystyczny" [melioristic] by the authors, i.e. connected with the conviction that the development of the political and legal thought was a steady progress,

${ }^{40}$ M. Niemczyk, Historia doktryn polityczno-prawnych $w$ świetle europejskich i krajowych ram kwalifikacji [The history of the political and legal doctrines in light of the European and domestic framework of qualification] [in:] M. Maciejewski, M. Marszał, M. Sadowski (eds.), Tendencje rozwojowe... [Developmental tendencies...], pp. 247-261.

${ }^{41}$ In: M. Jaskólski, 13 różnych esejów o historii myśli politycznej i nie tylko [13 different essays on the history of political thought and more], Warsaw 2013, pp. 45-75. 
which is connected with the historical approach above all. This extensive text, which indicates various models of practising the discipline, contains a very clear warning concerning the hitherto historical portrayal of doctrines however. It is worth quoting them:

To, co dotąd zostało już powiedziane, skłania nas do wniosku, że dotychczasowe ujęcie przedmiotu prowadzi $\mathrm{w}$ dhuższej perspektywie do wykluczenia doktryn z zakresu ściśle pojętych nauk prawnych, czyniąc z nich przedmiot o nikłym znaczeniu zarówno $\mathrm{w}$ edukacji prawniczej, jak i w sferze badań nad prawem oraz w zakresie praktyki prawniczej. [What has already been said disposes us to reach the conclusion that the hitherto approach to the subject leads, in a longer perspective, to the exclusion of doctrines from the range of strictly understood legal sciences, making it a subject of slender significance in both legal education and in the sphere of research into law as well as in the scope of legal practice]. ${ }^{42}$

Nextly, a text by Michał Jaskólski entitled Po co nam teoria, po co nam metodologia [Why do we need the theory, why do we need the methodology], which is also included in this collection, contains remarks pertaining to the lecture, which should indeed be limited in its historical layer but should not do away with its chronological structure, and it should move away from the Eurocentric approach. Finally, it should take into account the Polish political thought from the $15^{\text {th }}$ to the $20^{\text {th }}$ century as equivalent exactly due to the fact that it is the topic of the current political debates. Moreover, it should assume:

[...] powrót (po okresie rozbratu) do doktryn o profilu prawnym wywierającym wyraźny wpływ na oblicze polityki, co od drugiej połowy XX w. wydaje się faktem i trwa nadal, czego dowodem są nie tylko różne koncepcje prawa naturalnego i pozytywizmu, lecz i doktryny państwa prawnego czy państwa prawa znów sięgające do swych historycznych zaszłości [a return (after a period of separation) to the doctrines with a legal profile which exert a distinct influence on the face of politics, which seems to be a fact since the second half of the $20^{\text {th }}$ century and it continues still, which is proved not only by various concepts of natural law and positivism but also by the doctrine of the rule of law or of the legal state which also draw on their historical past]. ${ }^{43}$

${ }^{42}$ M. Maciejewski, T. Scheffler, O doktrynologii: rozważania dotyczace przedmiotu oraz metody doktryn politycznych i prawnych [Doctrinology: ruminations concerning the subject as well as the method of political and legal doctrines] [in:] I. Barwicka-Tylek, A. Czarnecka, M. Jaskólski, J. Malczewski (eds.), Myślenie o polityce i prawie... [Thinking about politics and law...], pp. 263-297, quote from p. 275.

${ }^{43}$ M. Jaskólski, Po co nam teoria, po co nam metodologia? [Why do we need the theory, why do we need the methodology] [in:] I. Barwicka-Tylek, A. Czarnecka, M. Jaskólski, J. Malczewski (eds.), Myślenie o polityce i prawie... [Thinking about politics and law...], pp. 555-572, quote from p. 570 . 
The methodological debate was initiated not only by the political change and the political transformation but also by the state authorities. In particular, the actions of the Ministry of Science and Higher Education which were aimed at adjusting the Polish educational standards to the European ones on the one hand and, on the other hand, it stemmed from the intention to make studies more practical, especially legal studies.

Cutting down the number of hours devoted to the teaching of the subject happened first. As a rule, the subject was also relegated to the first year of studies and it frequently became an optional subject. At the same time, the point system resulted in the fact that students received fewer points for obtaining credit, especially when the subject was compulsory. The growth of the contents of the subject and the repeated accusations that the coursebooks turned into "phone books," a generally negative attitude towards an overly historical method of teaching law, an attitude oriented towards acquiring a profession as fast as possible, were omnipresent and they were also markedly present in the decisions made by the authorities. Ryszard Skarzyński wrote about this tendency accurately and succinctly, albeit extremely bitterly. It is enough to quote the title of his article here, "Ewolucja znaczenia historii doktryn politycznych i prawnych w warunkach przekształcania uniwersytetu w zakład usługowy" [The evolution of the significance of the political and legal doctrines in the conditions of the transformation of universities into service companies]. In this article, the author differentiated between two different types of legal studies in the conclusions, namely "wykształcenie prawnicze" [legal education] and "wyszkolenie prawnicze" [legal training $]^{44}$.

Moreover, the name "Doktryny polityczno-prawne" [Political and legal doctrines] was officially introduced into minimum curriculums instead of "Historia doktryn" [The history of doctrines]. Perhaps this saved the subject as historical subjects were generally given very little respect. Simultaneously, there were frequent attempts to modernize didactics, especially in case of tutorials. Young adepts of the discipline started to widely employ the method of Oxford-style debates as it was supposed to at least provide soft competences, discussion skills, etc. During the conference in Cracow in 2014, 11 papers were presented which were devoted to the didactics of political and legal doctrines, including three papers devoted to the Oxford-style debate. ${ }^{45}$

${ }^{44}$ R. Skarzyński, Ewolucja znaczenia historii doktryn politycznych i prawnych $w$ warunkach przeksztatcania uniwersytetu $w$ zaktad ustugowy [The evolution of the significance of the political and legal doctrines in the conditions of the transformation of universities into service companies] [in:] M. Maciejewski, M. Marszał, M. Sadowski (eds.), Tendencje rozwojowe... [Developmental tendencies...], pp. 135-150.

${ }^{45}$ I. Barwicka-Tylek, A. Czarnecka, M. Jaskólski, J. Malczewski (eds.), Myślenie o polityce i prawie... [Thinking about politics and law...], with papers by M. Baranowska, Dlaczego dok- 
An example of the change in teaching, which was brought about by the officially changed name of the subject of "Doktryny polityczno-prawne" [Political and legal doctrines] instead of the hitherto employed "Historia doktryn polityczno-prawnych" [The history of political and legal doctrines], was a coursebook by Hubert Izdebski entitled Doktryny polityczno-prawne. Fundamenty wspótczesnych państw [Political and legal doctrines. The foundations of contemporary states]. ${ }^{46}$ This subject was qualified as a separate one from the history of doctrines by the author. He also based his conclusions on the regulation of the Minister of Science and Higher Education from the 12 July 2007 concerning the standards of education. Taking the above into consideration, Hubert Izdebski indicated that

[...] efektem studiowania $\mathrm{w}$ zakresie doktryn polityczno-prawnych powinno być uzyskanie przez studentów wiedzy z zakresu doktryn polityczno-prawnych dominujących we współczesnym dyskursie politycznym, zrozumienie doktrynalnych źródeł instytucji politycznych i prawnych, jak również nabywanie zdolności dokonania wykładni obowiązującego systemu prawa w kontekście ich doktrynalnego uzasadnienia [the effect of studying political and legal doctrines should be the acquisition of knowledge from the area of political and legal doctrines which dominates the contemporary political discourse by students, the understanding of doctrinal sources of political and legal institutions as well as the acquisition of the ability to make an interpretation of the binding legal system in the context of their doctrinal justification]. ${ }^{47}$

Hubert Izdebski's coursebook was based on these official indications and it was an attempt to present the roots of extremely contemporary issues concerning the state and law. His composition is not historical. Elements of historical information are intertwined with specific practical issues. As an illustration, it is worth

tryny polityczno-prawne sa potrzebne prawnikom? Debata oxfordzka jako forma ćwiczeń [Why political and legal doctrines are necessary for lawyers? The Oxford debate as a form of classes] (pp. 371-381); M. Maj, M. Urbańczyk, Doktryny polityczno-prawne jako przestrzeń do zdobycia kompetencji miękkich [Political and legal doctrines as a space to acquire soft competences] (pp. 469-485); M. Niemczyk, Debata oxfordzka jako skuteczna metoda osiagania efektów ksztatcenia z zakresu historii doktryn polityczno-prawnych [The Oxford debate as an effective method of achieving learning outcomes in the field of the history of political and legal doctrines] (pp. 513-539).

${ }^{46}$ H. Izdebski, Doktryny polityczno-prawne. Fundamenty wspótczesnych państw [Political and legal doctrines. The foundations of contemporary states], Warsaw 2012 ( $1^{\text {st }}$ edition: 2010).

${ }^{47}$ Ibidem, p. 16. These standards are still in force, despite the larger autonomy of universities in establishing their own curriculums, and it took place by virtue of the act of 18 March 2011 which changed "Prawo o szkolnictwie wyższym, ustawy o stopniach naukowych i tytule naukowym oraz o stopniach i tytule w zakresie sztuki oraz o zmianie niektórych innych ustaw" [The law on higher education, the acts on academic degrees and on an academic title as well as on degrees and a title in the field of arts as well as on the change of certain other acts] (Journal of Laws, No. 84, item 455, as amended). 
describing the structure of this coursebook. The first part is entitled "Ideologiczne kierunki współczesnego myślenia o społeczeństwie, państwie i prawie" [Ideological directions of contemporary thinking about society, the state, and law]; part two is "Wartości, zasady i prawa podstawowe we współczesnej demokracji liberalnej" [The values, principles, and fundamental rights in a contemporary liberal democracy]; and the third part is called "Doktrynalne podstawy demokratycznego państwa prawnego" [Doctrinal foundations of a democratic legal state]. Elements concerning the knowledge of the past and the development of the idea are provided, in a way, incidentally. For example, in part three, chapter twelve entitled "Wolność a demokracja" [Liberty and democracy], the European Convention on Human Rights is recalled which delineates a democratic system of government and later it discusses the understanding of democracy by mentioning Aristotle, Constant, John Locke and John Stuart Mill. ${ }^{48}$ Admittedly, the first part discusses the directions of ideological thinking by differentiating between those with a tradition of more than one hundred years and those which were born in the $19^{\text {th }}$ century as well as "Kierunki ostatniego stulecia" [The directions of the last century]. However, they do not delve deeply into particular authors. They are brought to mind in fragmentary phrases. This coursebook really makes it easier to find the predecessors of certain contemporary legal ways of reasoning. On the other hand, it does not show development and continuation at all. It is the author's personal opinion that it is more challenging for students to learn and understand it than the traditional doctrine coursebooks which approach them from a "historical" perspective. It is definitely right and proper to present the roots of contemporary thinking about the state and law but it would be necessary to devote more space to these roots, however.

To sum up the present ruminations, one can say in short that the debates concerning the shape of the subject are held constantly. However, it is the author's opinion that a question hides behind these debates - what do lawyers actually need doctrines for? Naturally, it would be good to indicate that an erudite lawyer could recall the Aristotle's principles of distributive and restorative justice and relate them to the verdict of the Constitutional Court; ${ }^{49}$ that the court could call on the internal morality of the law while considering the issue of the disclosure obligation pertaining to the binding law; such lawyer could also think through and remember

${ }^{48}$ Ibidem, pp. 323-241.

49 Excellent examples of using the knowledge of doctrines by lawyers in practice is presented by M. Rupniewski, Doktryny polityczno-prawne jako narzędzie interpretacyjne na przykładzie pojęcia sprawiedliwości w orzecznictwie Trybunatu Konstytucyjnego [Political and legal doctrines as an interpretation tool on the example of the term "justice" in the judicial decisions of the Constitutional Tribunal] [in:] I. Barwicka-Tylek, A. Czarnecka, M. Jaskólski, J. Malczewski (eds.), Myślenie o polityce i prawie... [Thinking about politics and law...], pp. 541-554. 
the meaning of the term rule of law in its historical development and realize that it does not only mean formal legality but the contents of this term are much broader. Moreover, such lawyers could also possess knowledge pertaining to various ways of understanding of the contents of the phrase "prawo natury" [natural law]. Incessant attempts to give lawyers practical education are bound to end in restricting their intellectual horizons sooner or later. A significant argument is the fact that lawyers do not study economics, sociology, or philosophy anymore. This makes doctrines almost the only subject in the curriculum which connects students with philosophy, economics, or with broadly understood "kultura w ogóle" [culture in general]. They broaden the horizons of a lawyer's way of thinking and it can warn them of excessive legal positivism which led to a situation in which every Nazi judge who was among the defendants after the main Nuremberg trials claimed that they only followed the law and that the death penalty was the only punishment possible according to the criminal law.

As Lech Dubel rightly noticed:

Badania historycznodoktrynalne nie są tylko intelektualną rozrywką grupy fascynatów, lubiących wychodzić poza zwykłe, prawnicze rzemiosło. Tworzą humanistyczną postawę studentów i absolwentów studiów prawniczych, w znaczący sposób wpływając na rozwój kultury prawniczej i politycznej. [Doctrinal and historical research is not only intellectual entertainment of a group of enthusiasts who enjoy stepping out of the circle of the ordinary legal trade. They create a humanistic attitude among students and graduates of legal studies and they significantly influence the development of legal and political culture]. ${ }^{50}$

The author would suggest putting the greatest emphasis on this aspect of general education of the subject: even if the subject is erudite and difficult, is it really a reason to get rid of it? Should erudition be a cause for shame? Taking into consideration that many lawyers do not work in strictly legal professions, would it not be better to broaden their horizons instead of limiting them as much as possible? And maybe Savigny was right to a certain extent when he said the following words:

[...] nauka prawa, która nie opiera się na gruntownym badaniu historycznym, spełnia właściwie tylko funkcje pisarza w praktyce sądowej [the study of law, which is not based on a thorough historical study, only serves the function of a clerk in court practice]. ${ }^{51}$

${ }^{50}$ L. Dubel (ed.), Idee jako źródło... [Ideas as a source...], foreword, p. 9.

${ }^{51}$ Quoted after: H. Olszewski, M. Zmierczak, Historia doktryn politycznych i prawnych, Ars boni et aequi [The history of political and legal doctrines, Ars boni et aequi], Poznań 1994, p. 211. 
Constitutions, laws, or other legal acts are very easily changed; however, understanding their contents requires reflection upon justice, upon the organization of the state, and upon the values which law makes real. The author is afraid that the bitter words of the editors of the work which were frequently quoted here are still current. They wrote in the preface:

Znamienne, że dwadzieścia kilka wieków po niesławnym procesie lud ateński versus Sokrates zmuszani jesteśmy stawiać czoło podobnym zarzutom pod adresem własnej działalności. Podobnie jak Sokrates nie mamy wielkich szans na korzystny wyrok. Jak on niegdyś demoralizował młodzież, tak i my marnujemy jej kosztowny czas, przeciążając studentów wiedzą "zawodowo niepotrzebną". Jak on niegdyś oburzał bogów ateńskich, tak teraz my drażnimy bóstwa ekonomii, które nakazują legitymizować się tylko taką wiedzą, która "zwiększa szansę na rynku pracy." [It is significant that more than twenty centuries after the infamous case of the people of Athens versus Socrates that we are forced to face similar charges against our own activity. Similarly to Socrates, we do not have great chances of a favourable ruling. As he demoralized youths one day, so do we waste their precious time by overburdening students with "professionally unnecessary" knowledge. As he once outraged Athenian gods, so do we now vex the deities of economics, which order us to hold only such knowledge which "gives us a better chance on the job market"]. ${ }^{52}$

${ }^{52}$ From the editors [in:] I. Barwicka-Tylek, A. Czarnecka, M. Jaskólski, J. Malczewski (eds.), Myślenie o polityce i prawie... [Thinking about politics and law...], p. 10. 